\title{
THE CULTURAL VALUES OF BATAK TOBA IN BATU GANTUNG LOCAL TRADITION IN SAMOSIR ISLAND
}

\author{
PANi Gultom $^{1}$, Muhammad NATSIR ${ }^{2}$, FauZiah Khairani Lubis ${ }^{3}$ \\ ${ }^{123}$ UNIVERSITAS NEGERI MEDAN
}

\begin{abstract}
The research was found on the topic about The Cultural Values of batak Toba in Batu Gantung Local Tradition in Samosir Island. This study was conducted by applying descriptive qualitative method. The source of data was taken from the informants who live around Samosir Island, Kabupaten Simalungun. The technique for analyzing the data is descriptive qualitative research based on The Cultural Values in Sibarani (2013). The result of this research was The Cultural Values of Batak Toba in Batu Gantung Local Tradition in Samosir Island are Seeing Each Other Frequently, Honesty (30\%), courtesy, social solidarity, harmony and conflict resolution (60\%), welfare, hard work, discipline, mutual cooperation, gender management (80\%) and education, health, cultural preservation and creativity, environmental concern, peace, commitment, positive thoughts, and gratitude. (100\%).
\end{abstract}

Keywords: Cultural Values, Local Tradition

\section{INTRODUCTION}

Indonesia is a rich country with culture and custom as heritage that spread from Sabang to Merauke. There are many islands and tribes in Indonesia with different custom, cultures and languages. Every tribe has its own uniqueness and it is preserved until now. For example, in North Sumatra people preserve the oral tradition such as Batu Kursi Persidangan, Pusuk Buhit, etc. The culture of a given society comprises the shared values, understandings, assumptions, and goals learned from earlier generations, imposed by present members of a society, and pass onto succeeding generations.

\subsection{Semantic}

Semantic is the branch of linguistics which deals with meaning. As Palmer (1976:1) says, semantics is the technical term used to refer the study of meaning. The term semantics is derived from a Greek, semantic from semanio "to signify" or "mean". Semantic is the study about meaning in language.

\subsection{Culture}

Culture is classified into its material and non-material aspects Gabriel E (2015:4). Material culture refers to the visible tactile objects which man is able to manufacture for the purposes of human survival; non-material culture comprises of the norms and mores of the 
people. While material culture is concrete and takes the form of artefacts and crafts, nonmaterial culture is abstract but has a very pervasive influence on the lives of the people of a particular culture.

\subsection{Batak Toba}

Toba Batak, is an ethnic group of many Batak clans found in Sumatra. The Toba Batak tribal settlement area includes the Toba Samosir district consisting of Balige, Laguboti, Parsoburan and its surroundings. The Toba Batak people have a clan that shows the identity of the descendants they came from. The name of the clan is obtained from their father which will then be passed on to the male offspring continuously. According to the Batak people, "children" (boys) are kings, while "boru" (daughters) means clans break up there.

\subsection{Local Tradition}

Tradition is complex which includes knowledge, beliefs, arts, morals, laws, customs and others relating to human abilities and habits as member society.

Selo Soemardi as quoted by Purwanto S.U, argues, that culture is all the result of creation, intention human taste and work in society. Whereas according to Mursal Esten, tradition is a habit of descending a group of people based on valuesthe culture of the community concerned. Tradition show community members behave, both in life which is occult or religious.

\subsection{Legend}

Legend traditions are particularly interesting because they are central tools in the social negotiation of these models. An overview of a culture's legends is also a reflection of its visions, conceptions, fears and fantasies as these are conventio-nally realized and negotiated through discourse. This makes legend indices a valuable resource for research in numerous areas. (Elore:2012)

\subsection{Batu Gantung Local Tradition}

Batu Gantung is one of local traditions from Samosir Island. Batu Gantung is famous for its mystical thing. Long ago there was a beautiful girl in Parapat, buther parents match their daughter by a youngman. Eventhough, their daughter has a relationship with a young man who had become her boyfriend. She refused the suggestion of her parents to marry someone else and preferred her boyfriend. Because she felt hesitant to refuse her parents' urge, she was depressed and felt sorry for her parents for being a topic in their village. After returning from the fields, the girl did not go home, but preferred to sit alone and brood on the edge of Lake Toba accompanied by her beloved dog named Toki. When the night come, the girl go home with a blank mind. Without realizing, she did not see a large hole in the road, then fell into the hole. When her dog see his employer fell into the hole, it barked to ask someone for help. In the hole, 
the girl preferred to die rather than bear the shame of refusing someone else's proposal. She shouted loudly from inside the hole, "Come close ... get it." The wall of the stone was closer and squeezes the girl. Not long after the earthquake shook the ground, the land around Lake Toba felt and left only a pile of stones where the girl's hole was and become a hanging stone. The hanging stone is shaped like a human.

\section{METHODOLOGY}

The design of this research was conducted with descriptive qualitative design. Descriptive research is a research method which describes the condition, evens or situation. Badgonand Taylor stated in Salim (2009:45) says that descriptive qualitative method refers to the research procedure which produce descriptive data : people own language, or written words and observable behaviours and seeks to provide the goals using the data in form of words, this research is not using number (quantitative). The sources of the data was the story of Batu Gantung local tradition in Parapat, Samosir Island. The data would be supported with the result of interviewing informant as native speaker and know about the story of Batu Gantung local tradition.

\section{FINDINGS}

\subsection{Cutural Values of Batak Toba in Batu Gantung Local Tradition}

\subsubsection{Welfare}

In the previous chapter the welfare is explained as a type of government support for the citizens of that society. Welfare may be provided to people of any income level, as with social security ( and is then often called a society safety net), but it is usually intended to ensure that the poor can meet their basic human needs such as food and shelter. Welfare attempts to provide poor people with a minimal level of well-being, usually either a free or a subsidized supply of certain goods and social service, such as healthcare, education, and vocational training. This value is found in Batu Gantung Local Tradition. The discussion is as the following:

- Disada huta tinggal ma sada keluarga namora. Jabuna balga, horbona godang, haumana bidang jala lombuna pe godang

In some village lived a rich family. Their house is very big, they have a lot buffalos, a large field, and also cows that many. (at that time the people who have many pets are considered wealthy).

- Ala tamba do sangap ni sada keluarga molo dipangolihon anakkonna jala marpahoppu paima so marujung ngoluna.

The family would be more prosperous if they married their children and had a grandchildren before they died. In bataknese there are a tradition if they see all of their children 
got married and have a grandchildren before they died they feel completed. It feels like their all their obligation in the world has done and they will be calm even they had die.

\subsubsection{Hard work}

Hard work is an activity that is done seriously without stopping before the target work is achieved. It is not a question here of demanding or strenuous work. This kind of work is a negative good, and it commonly carries other negative goods in its train: poverty, insecurity, ill health, physical danger, dishonor and degradation. And yet it is socially necessary work; it needs to be done, and it means that someone must be found to do it.This value has found in Batu Gantung Local Tradition. The discussion is as the following:

\section{Dungi dipasahat ma tu inang ni seruni i jala ittor dihobasi ma na hombar tusi}

After Seruni's father said that seruni has to marriage in this week, Seruni's mother prepared for her daughter wedding ceremony. In bataknese the bride family feel so respected if their daughter got marriage.

\subsubsection{Discipline}

Discipline is action or inaction that is regulated to be in accordance (or to achieve accord) with a particular system of governance. Discipline is commonly applied to regulating human and animal behavior, and furthermore, it is applied to each activity-branch in all branches of organized activity, knowledge, and other fields of study and observation. This value is found in Batu Gantung Local Tradition. The discussion is as the following:

Ro ma si Seruni neng manjalo ijin tu amongna neng mardalani rohana tu parmonasan

Seruni asked a permission to her father because she wanted to go to some places. Seruni was a disciplined girl because she didn't go anywhere without permission.

\subsubsection{Education}

Education is the process of facilitating learning, or the acquisition of knowledge, skills, values, beliefs, and habits. Educational methods include storytelling discussion, teaching, training, and directed research. Education can take place in formal and informal settings and any experience that has a formative effect on the way one thinks, feels, or acts may be considered educational.This value has found in Batu Gantung Local Tradition. The discussion is as the following:

Alai manang songon dia pe huoloi pe hata muna i among inong. Dang paloason ku hamu tarila di huta on. Ikkon sangap do hamu bahenonku.

I have to say that, I would take your advice Mom, Dad. I would not let you ashamed in this village. I would make you proud of me. Seruni do not want to make her parents ashamed in the village, she do everything her parents said although inside she felt so sad because she had to 
against her promise with a guy she loved.

\subsubsection{Health}

Health is a condition of the body and mind and the degree to which it is free from illness, or the state of being well.This value is found in Batu Gantung Local Tradition. The discussion is as the following:

Mabiar ma among ni si Seruni on alana ro udan dohot ronggur diparlao ni si Seruni on. Atik boha tarsiladdit patna di robean ni Sibaganding an.

Seruni's father worried about Seruni's health because that situation rainy at the time, when Seruni went. He worried Seruni will fall down to the edge of the lake, because when Seruni went such a rainy rain and the lightning is very powerful and of course the streets was slippery because of rain.

\subsubsection{Mutual cooperation}

Mutual cooperation is the process of groups of organisms working or acting together for common or mutual benefit,as opposed to working in competition for selfish benefit. This value is found in Batu Gantung Local Tradition. The discussion is as the following:

Jala didok ibana ma asa rappak mangaluli nasida paima so torang dope ari. Rap mangalului si seruni ma nasida di tonga borngin.

He said that, they would look for Seruni together, before the sunset came. So, they looking for Seruni together in the middle of the night. They worried if the sun came, their neighbor would see them and know about their problem. Because in bataknese that such a embarrassing problem.

Jala denggan do mardalan pesta ni nasida ala pangurupion ni akka jolma.

The wedding party went so well because other people also helped them. In the village if their neighbor had a ceremony such as wedding ceremony they will be help them to prepare the wedding such as cleaning their house, cooking for the food, ect.

\subsubsection{Gender management}

Organizational and managerial realities construct, sometimes re-form and even subvert, dominant gender relations. When 'gender' is considered, whether in theory or practice, it is still common to focus on 'men and women' and 'relations between them'. While these are certainly key aspects of gender relations, they are only part of it. Gender is just as relevant in relations between women, and between men. Sex and sex differences are often naturalized as fixed in biology.This value is found in Batu Gantung Local Tradition. The discussion is as the following:

Ala naung muli si Seruni tu anak ni namboru na, laos dohot ma ibana tu jabu ni na nanung 
simatua nai songon biasa adat ni halak batak.

Because Seruni was married, she lived in her Namboru's house. It is one of the norms of Bataknese. So if the girls of bataknese got married they will follow her husband, if their husband did not have a house yet, they can lived in their husband parent's house.

\subsubsection{Cultural preservation and creativity}

Preservation is a grounded effort, and this basis is called also the factors that support it both from within and from outside of the things preserved. Therefore, a process or action conservation recognizes strategies or techniques based on needs and their respective conditions.Being a provision in cultural preservation will be a form of culture, which means that a culture is preserved indeed is still there and known, although in its development it is increasingly forgotten. This value is found in Batu Gantung Local Tradition. The discussion is as the following:

Didokkon ma anggo boru ni raja i ikkon sangap do bahenon ni nasida jala ikkon makkuling do sude ogung jala ikkon jouon do sahuta nang dohot raja ni huta.

They told that Seruni should be treated like the daughter of the king, they extended all the culture by the traditional music, called ogung and they also invited the king in the village.

\subsubsection{Environmental concern}

Environmental concerns express general attitudes toward the quality of the environment embodied in the willingness of self to declare actions that can improve and maintain the quality of the environment in any behavior related to the environment.The discussion is as the following:

Ala tamba do sangap ni sada keluarga molo dipangolihon anakkonna jala marpahoppu paima so marujung ngoluna.

In Bataknese culture, when the parents let their children get married before they pass away they will be welfare.The family would be more prosperous if they married their children and had a grandchildren before they died.

\subsubsection{Peace}

Peace is the concept of harmonious well-being and freedom from hostile aggression. In a social sense, peace is commonly used to mean a lack of conflict (such as war) and freedom from fear of violence between individuals or heterogeneous (relatively foreign or distinct) groups.This value is found in Batu Gantung Local Tradition. The discussion is as the following: Adongma anak nasida sada namargoar si pulik jala ala nga matua daging nasida sihol ma roha nasida naeng pangolihon anak sasada nasida $i$.

They have a son, called Purlik. Their son has been old, so they planed to marry him to the daughter of their family. 


\subsubsection{Courtesy}

Courtesy is the rules of life that arise from the outcomes of the group. The norm of politeness is relative, meaning what is perceived as a norm of decency varies in different places, environments, or times. Examples of norms of courtesy are: respect older people, receive something always with your right hand, do not say dirty, rude, and arrogant, No spitting anywhere, not interrupting the conversation. This value is found in Batu Gantung Local Tradition. The discussion is as the following:

Didok ibana boasa ma dung magodang pamatangku among inong dipaboa hamu na songonon? Alai manang songon dia pe huoloi pe hata muna i among inong. Dang paloason ku hamu tarila di huta on.

She said that, why you told me now mom, dad ? however, I must take your advice, I will not let you ashamed in this situation. Because Seruni do not know that her parents make a promise to with their family to match Seruni and their son when they an adult.

\subsubsection{Honesty}

Honesty is telling the truth or able to be trusted and not like to steal, cheat or lie. This value is found in Batu Gantung Local Tradition. The discussion is as the following:

Dipaboa si Seruni ma parsonduk bolonna ibana.

Seruni told that she is Purlik's wife.

\subsubsection{Social solidarity}

Social solidarity is the relationship between individuals or group that form the morals and beliefs experienced and reinforced by shared emotional experiences. Although the issue of social solidarity has the potential to pose difficulties for many other subjects in the social sciences and beyond, it is in sociological works that the problem is confronted most frequently and directly. This value is found in Batu Gantung Local Tradition. The discussion is as the following:

Jala na hombar tusi pe nga dipasahat tu hula-hula i tarsongon mas, horbo nungnga denggan dipasahat tu nanaeng hula-hula nasida $i$.

And Purlik's parents (as hula-hula) have prepared all the things as the usually terms that they need in the wedding like, some golds and buffalos.

\subsubsection{Harmony and conflict resolution}

It means compatible, able to exist in peace or agreement, or things that fit together well. This can relate to many conditions in life. For instance, two or more musical instruments working together to produce a pleasing sound fitting together to make a complete sound. This value is found in Batu Gantung Local Tradition. The discussion is as the following: Mangido salah ma among ni si Pulik on taringot tu halao ni si Seruni. Jala didok ibana ma asa 
rappak mangaluli nasida paima so torang dope ari. Rap mangalului si seruni ma nasida di tonga borngin.

Purlik's parents beg for a pardon because of that trouble, and He said that, they would look for Seruni together, before the darkness came.

Tubu ma rohana naeng lao sian jabu ni simatua nai. Paima golap ari asa unang adong na mamereng ibana. Naeng lao ma ibana sian i naeng manikkot ala ni lungun ni rohana. Lao ma ibana sip-sip

Seruni wanted to leave her mother-in-law's home. She wanted to end her life because she was very sad. So she left the house without saying anything.

\subsubsection{Commitment}

A commitment obligates you to do something. Some commitments are large, like marriage. When you take a job, you're making a commitment to show up and do the job well, and your employer makes a commitment to pay you. There are smaller commitments too. If you said you'd meet a friend at six, that's a commitment show up or your friend will be mad. You also can speak of commitment as a quality. This value is found in Batu Gantung Local Tradition. The discussion is as the following:

Dijua si Seruni on ma hatani amongna alana nga adong hata ni anak ni halak naung dijalo ibana.

Seruni refused her father's plan, because she has a boyfriend that she wants to get married.

\subsubsection{Positive thoughts and gratitude}

Positive thinking is a mental attitude in wich you expect good and favorable results. In other words, positive thinking is the process of creating thoughts that create and transform energy into reality.gratitude is more than feeling thankful for something, it is more like a deeper appreciation for someone (or something,) which produces longer lasting positivity.This value is found in Batu Gantung Local Tradition. The discussion is as the following:

Dipaloas ma nasida lao alana dipikkiran ni amang ni si Seruni ala naga balga boruna ikkon loason do mardalani asa terbuka pikkiranna.

Seruni's father finally let her go because he thought that her daughter was anadult and so that she cored have broaden horizon of thinking.

\subsection{The reflection of cultural values of Batu Gantung local tradition in the society}




\section{Table 2.1 The reflections of Cultural Values in the Society}

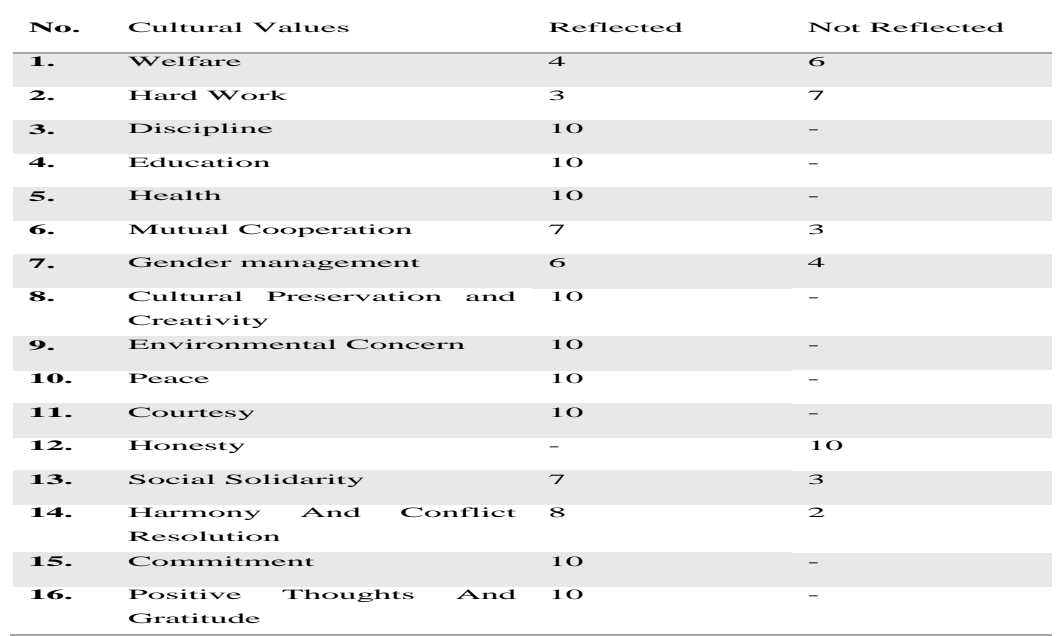

\section{CONCLUSIONS AND SUGGESTIONS}

After analyzing the cutural values of Batak Toba in Batu Gantung Local Tradition, the conclusion can be drawn as follows:

1. The sixteen cultural values are found in Batu gantung Local Tradition; they are welfare, hard work, discipline, education, health, mutual cooperation, gender management, cultural preservation and creativity, environmental concern, peace, courtesy, honesty, social solidarity, harmony and conflict resolution, commitment, positive thoughts, and gratitude.

2. There are 7 culture values that are still reflected in the society; they are commitment, positif thoughts and gratitute, peace, environmental concern, education, health, and cultural preservation and creativity.

3. One of the cultural values is not reflected in the society, which is honesty.

\section{REFERENCES}

Amir, Andriyetti. (2013). SastraLisan Indonesia. Yogyakarta: Andi.

Amiruddin,S. (2016). Intergration of Local Literature Values in The Implementation of 2013 Curriculum. International Journal of language Education and Culture Review. Volume 2 No. 1 24. 17 Februari 2017

Crow, Graham. (2012). Classical Theories Of Social Solidarity. British Library : Philadelphia.

Duranti, Alessandro. ed. (2001). Linguistic Anthropology. Massachusetts: Blackwell

Endraswara, Swardidkk. (2013). Foklore Nusantara. Yogyakarta: Penerbit Ombak

Endraswara, Swardi dkk. (2013). Foklore and Folklife Kesatuan dan Keberagaman. Yogyakarta: 
Penerbit Ombak

Finnegan, R. (2013). Oral Literature in Africa. Translation Journal Volume 15 No. 3 Februari 2017

Gascon.D. (2015). Oral Literary Tradition Manual for K-12 Revised andCurricula on Literature, History, and Social Studies. International Journal of Languages, Literature and Linguistics. Volume 1 No. 2. 13 Februari 2017.

Gabriel, E. (2015). African Culture And Values. Department of Philosophy : Nigeria

Guan,K. (2000). Manfaat Kesaksian Lisan: Teks dan Kelisanan dalam Rekonstruksi Masa Lampau dalam Sejarah Lisan di Asia Tenggara: Teori dan Metode (terj), Jakarta: LP3ES

Hill, Thomas. (2015). Peace making and Peace building. New York University.

Humaeni, A. (2012). The Local Tradition of Magical Practices in Banten Society. Faculty of Tarbiyah and Adab at IAIN "SMH" Banten

Jenks, C. (1993). Culture: Studi Kebudayaan, Terjemahan oleh Erika Setyawati (2013). Yogyakarta: Pustaka Pelajar

Johan, R. et. all. (2017). Education Nowdays. Gunadarma University:Depok.

Sibarani, R. (2007). Nilai Budaya Batak Toba. Jakarta: Sanggar Williem Iskandar.

Sibarani, Robert. (2004). Antropolinguistik: Antropologi Linguistik dan Linguistik Antropologi. Medan: Penerbit Poda.

Sibarani, R. (2012). Kearifan Lokal: Hakikat, Peran, Metode Tradisi Lisan. Jakarta: Asosiasi Tradisi Lisan (ATL).

Sibarani, R.(1999). Pemetaan Tradisi Lisan di Sumatera Utara. Jakarta:Asosiasi Tradisi Lisan (ATL).

Spener, K. (2011). An analysis of Navaho Chantway Myths Memories of the American Foklore Society. Volume 23, No. 2. 13 Februari 2011.

Vosu, E. (2012). Smoking Out Local Traditions? Identity And Heritage Production In Southeast Estonian Rural Tourism Enterprises 